\title{
PRAGMATIK; KONSEP DASAR MEMAHAMI KONTEKS TUTURAN
}

\begin{abstract}
Abdurrahman
Dosen Jurusan Bahasa dan Sastra Arab

Fakultas Humaniora dan Budaya, Universitas Islam Negeri (UIN) Malang.

Jalan Gajayana No. 50 Telepon (0341) 570872, Faksimile (0341) 570872 Malang 65144
\end{abstract}

\begin{abstract}
Pragmatics is a linguistics branch which maintains the use of context in understanding and produces speech. It is used to develop principles of work relationship and politeness in communication process, therefore, the aim of communication can be gained effectively. This context itself has relationship with culture which is different from one society to another society.
\end{abstract}

\section{Key words}

Pragmatics, context, communication, speech.

\section{Pendahuluan}

Bahasa merupakan alat utama dalam komunikasi dan memiliki daya ekspresi dan dan informatif yang besar. Bahasa sangat dibutuhkan oleh manusia karena dengan bahasa manusia bisa menemukan kebutuhan mereka dengan cara berkomunikasi antara satu dengan lainnya. Sebagai anggota masyarakat yang aktif dalam kehidupan sehari-hari, di dalam masyarakat orang sangat bergantung pada penggunaan bahasa. Hal ini sesuai dengan pernyataan bahwa "di mana ada masyarakat di situ ada penggunaan bahasa." Dengan kata lain, di 
mana aktivitas terjadi, di situ aktivitas bahasa terjadi pula (Sudaryanto dalam Djatmiko, 1992: 2).

Para linguis biasanya memberikan batasan tentang bahasa sebagai suatu sistem lambang bunyi yang bersifat arbitrer yang digunakan oleh sekelompok anggota msyarakat untuk berinteraksi serta mengidentifikasikan diri (Abdul Chaer, 1994). Di sisi lain setiap sistem dan lambang bahasa menyiratkan bahwa setiap lambang bahasa, baik kata, frase, klausa, kalimat, dan wacana saelalu memiliki makna tertentu, yang bisa saja berubah pada saat dan situasi terentu. Atau bahkan juga tidak berubah sama sekali.

Namun demikian, biasanya tidak banyak orang yang mempermasalahkan bagaimana bahasa dapat digunakan sebagai media berkomunikasi yang efektif, sehingga sebagai akibatnya penutur sebuah bahasa sering mengalami kesalahpahaman dalam suasana dan kontekstuturannya. Salah satu cara untuk mengetahui tentang hal itu adalah melalui sudut pandang pragmatik.

\section{Pengertian Pragmatik}

Istilah pragmatik sebagaimana kita kenal saat ini diperkenalkan oleh seorang filosof yang bernama Charless Morris tahun 1938. Ketika ia membicarakan bentuk umum ilmu tanda (semiotic). Ia menjelaskan dalam (Levinson, 1983:1) bahwa semiotik memiliki tiga bidang kajian, yaitu sintaksis (syintax), semantik (semantics), dan pragmatik (pagmatics). Sintaksis merupakan kajian lingustik yang mengkaji hubungan formal antar tanda. Semantik adalah kajian linguistik tentang hubungan tanda dengan orang yang menginterpretasikan tanda tersebut.

Sejak itulah, pragmatik mengalami dua perkembangan makna yang berbeda. Di satu sisi pragmatik dengan konsep sebagaimana yang dimaksudkan oleh Morris di atas tetap dipertahankan. Di sini istilah pragmatik digunakan dalam berbagai judul buku yang membahas masalah-masalah yang beragam seperti psikopatologi komunikasi dan evolusi sistem simbol. Di sisi lain, istilah pragmatik mengalami penyempitan makna. Dalam hal ini seorang Filosof sekaligus ahli logika 
yang bernama Carnap mengatakan bahwa apabila di dalam suatu penelitian terdapat rujukan yang konkret terhadap pembicara atau dalam istilah yang lebih umum, terhadap pengguna bahasa, maka dia menetapkan bahwa penelitian tersebut berada dalam bidang kajian pragmatik. Kemudian dalam perkembangan berikutnya, oleh Levinson (1983) pengertian tersebut dianggap terlalu sempit dan ekslusif; dan oleh karenanya pengertian tersebut dimodifikasi menjadi kajian bahasa yang bereferensi atau berhubungan dengan faktor dan aspek-aspek kontekstual.

Pembahasan pragmatik menurut Joko Nurkamto, pragmatik yang sekarang berkembang pada umumnya mengacu pada pengertian yang kedua dari di atas. Dalam hal ini Levinson (1983:21-24) menjelaskan kurang lebih tujuh pengertian pragmatik. Dan diantaranya adalah sebagai berikut:

Pertama, "Pragmatics is the study of the relation between language and context that are basic to an account of language understanding". Pengertian inimenunjukkan bahwa untuk memahami makna bahasa orang seorang penutur dituntuk untuk tidak saja mengetahui makna kata dan hubungan gramatikal antar kata tersebut tetapi juga menarik kesimpilan yang akan menghubungkan apa yang dikatakan dengan apa yang diasumsikan, atau apa yang telah dikatakan sebelumnya.

Kedua, "Pragmatics is the study of the ability of language users to pair sentences with the contexts in which they would be appropriate". Pengertian kedua ini lebih menekankan pada pentingnya kesesuaian antara kalimat-kalimat yang diujarkan oleh pengguna bahasa dengan konteks tuturannya.

Ada dua hal penting yang perlu di cermati dari pengertian pragmatik di atas, yaitu penggunaan bahasa dan konteks tuturan. Penggunaan bahasa di sini menyangkut fungsi bahasa (language functions). Untuk apa orang menggunakan bahasa? Beberapa ahli menjelaskan fungsi bahasa tersebut. Di antaranya adalah Van Ek dan Trim (1991), yang mengkategorikan fungsi bahasa menjadi 6 (enam) macam yaitu: 1) menyampaikan dan mencari informasi faktual, 2) 
Mengekspresikan dan mengubah sikap, 3) Meminta orang lain berbuat sesuatu, 4) Sosialisasi, 5) Membangun wacana, dan 6) Meningkatkan keefektifan komonikasi.

Masing-masing kategori tersebut di atas, dijabarkan kedalam beberapa subkategori yang lebih rinci dan praktis. Fungsi pertama, misalnya, dijabarkan menjadi 5 (lima) sub-kategori, yaitu: 1) mengidentifikasi atau mendefinisis, 2) melaporkan, mendeskripsikan atau menceritakan, 3) mengoreksi, 4) bertanya, dan 5) menjawab pertanyaan.

Adapun masalah konteks, menurut Dell Hymes (dalam James, 1980), meliputi 6 (enam) dimensi, yaitu: 1) tempat dan waktu (setting), seperti ruang kelas, di masjid, di ma'had, di perpustakaan, dan di warung makan, 2) pengguna bahasa (participants), seperti dokter dengan pasien, ustadz dan santri, penjual dengan pembeli, 3) topik pembicaraan (content) seperti politik, seks, pendidikan, kebudayaan, 4) tujuan (purpose) seperti bertanya, menjawab, memuji, menjelaskan, mengejek, dan menyuruh, 5) nada (key) seperti humor, marah, ironi, sarkasme, dan lemah lembut, dan 6) media/saluran (channel) seperti tatap muka, melalui SMS, melalui telepon, melalui surat, E-mail, dan, melalui tangan.

Dimasukkannya konteks dalam memahami dan atau menghasilkan ujaran dimaksudkan untuk membangun prinsip-prinsip kerjasama dan sopan santun dalam proses komunikasi, sehingga tujuan komunikasi dapat dicapai secara efektif. Konteks itu sendiri terkait erat dengan budaya, yang berbeda dari satu masyarakat ke masyarakat lain. Apa yang dianggap sebagai topik pembicaraan yang wajar oleh masyarakat Arab misalnya, mungkin dianggap sebagai topik pembicaraan yang absurd oleh masyarakat Indonesia, atau sebaliknya. Oleh karena itu, pengertian pragmatik yang diberikan oleh Levinson di atas, menurut hemat penulis, pada prinsipnya memberikan kerangka umum tentang bagaimana berkomunikasi secara tepat dan efektif dengan menggunakan bahasa sebagai medianya. Kenyataan bahwa 
konteks itu bisa berbeda-beda dari masyarakat satu ke masyarakat lain, dan hal ini tidak menjadi fokus bahasa Levinson.

Itulah sebabnya, Leech (1983) lebih suka menggunakan istilah Pragmatik umum (general pragmatics) untuk mengacu pada kajian tentang kondisi umum penggunaan bahasa untuk komunikasi. Ia mendasarkan gagasannya pada kenyataan bahwa prinsip kerjasama dan sopan santun dalam berkomunikasi berlaku secara berbeda-beda dalam setiap masyarakat.

Dalam pragmatik umum sama sekali tidak mengatur masalah itu. Bahkan menurut Leech, hal-hal yang bersifat lokal dan situasional dapat diatur dalam sosiopragmatik (sociopragmatics) dan pragmalinguistik (pragmalinguistics), karena kedua bidang ini merupakan cabang dari pragmatik umum. Sosio-pragmatik yang telah dikelaskan Leech (1983) memiliki kesamaan dengan istilah yang oleh Michael Canale (1983) di sebut dengan ketepatan isi (appropriateness in meaning), yaitu sejauh mana fungsi komunikasi tertentu, sikap dan gagasan dianggap tepat sesuai dengan situasi yang berlaku. Hal ini berhubungan erat dengan aspek sosiologi.

Sebagai ilustrasi, membicarakan pesta ulang tahun yang penuh dengan kegembiraan dengan teman-temannya pada saat menjenguk orang sakit keras di rumah sakit, hal ini secara konteks tuturan jelas tidak tepat. Sementara itu, pragmalinguistik menurut Leech kurang lebih sama dengan ketepatan bentuk (appropriateness in form) menurut Canale. Hal ini mengacu pada sejauh mana makna bahasa direpresentasikan ke dalam bentul verbal atau non verbal yang sesuai dengan konteks pembicaraan. Ini terkait erat dengan dengan tata bahasa yang sesuai dengan konteks pembicaraan. Sebagai contoh, seorang mahasiswa UIN yang berterima kasih kepada dosennya dengan hanya mengucapkan trims, atau memanggil Dosen /Ustadz hanya dengan menggunakan kata sapaan "Boss" biasanya di lingkungan UIN hal itu dianggap tidak sopan. Seyogyanya ia mengatakan, sekurang-kurangnya terima kasih Pak/Bu (Sykron Ustadz...) atau "Jam berapa Ustadz?" dan lainlain. Dengan kata lain, sosio-pragmatik ini sangat berkaitan dengan apa 
yang harus dikatakan dalam situasi tertentu, sedangkan pragmalinguistik berkenaan dengan bagaimana seorang penutur dapat mengatakan secara tepat.

Menurut Leech (1983:11) pragmatik umum, sosio-pragmatik, dan pragmalinguistik memiliki hubungan yang sinergis, hal ini dapat digambarkan sebagai berikut:

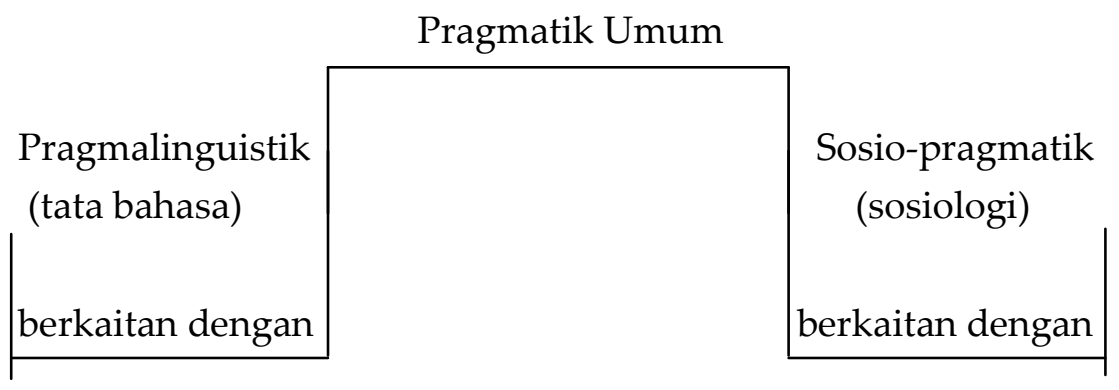

Seorang pemerhati linguistik, Jenny Thomas (1983) dalam artikelnya yang berjudul Cross cultural failure, mencoba membahas kegagalan pragmalinguistik dan kegagalan sosiopragmatik. Menurutnya, kegagalan pragmalinguistik pada dasarnya berkaitan dengan masalah bahasa, yang disebabkan oleh berbagai macam perbedaan penyandian fungsi bahasa; sedangkan kegagalan sosiopragmatik berkenaan dengan prilaku bahasa yang disebabkan oleh kurangnya pengertian lintas budaya (cross Culture). Oleh karena itu, apabila ada orang Indonesia yang mengajukan pertanyaan kepada orang Arab yang baru pertama kali ditemuinya dengan pertanyaan " $\mathrm{Hal}$ 'indak al fulus?" (Apakah anda punya uang?) misalnya, maka orang itu dianggap telah gagal berkomunikasi dalam kaitannya dengan aspek sosio-pragmatik, bukan pada aspek pragmalinguistik, karena secara tata bahasa kalimat di atas tidak salah. Dalam contoh di atas, bukan bahasanya yang salah tetapi pertanyaannya yang kurang tepat karena kurang sesuai dengan konteks dan situasi tutuannya. 


\section{Sejarah Perkembangan Pragmatik}

Sampai saat ini, kajian pragmatik sangat dikenal dalam dunia linguistik. Meskipun sebelumnya, di era 70-an banyak para linguis yang memperlakukan diskriminatif terhadap kajian pragmatik ini bahkan hampir tidak pernah membahasnya. Namun pada saat ini, banyak para linguis yang berpandangan bahwa mustahil bagi pemakai bahasa dapat mengerti secara baik sifat-sifat bahasa yang mereka gunakan dalam berkomunikasi tanpa mengerti hakekat pragmatik, yaitu bagaimana bahasa sebagai alat komunikasi dapat digunakan sebagaimana mestinya.

Senada dengan hal di atas, Joko Nurkamto (2000) menjelaskan bahwa kajian di bidang pragmatik mulai berkembang pada tahun 1971, yang ditandai dengan diterbitkannya Journal of Pragmatics yang memuat persoalan-persoalan pragmatik. Sebuah organisasi bernama IPRA (International Pragmatics Association) didirikan, dan beberapa konferensi tentang masalah pragmatik diselenggarakan (Soemarmo, 1988). Munculnya minat di bidang pragmatik tersebut dipicu oleh beberapa alasan, salah satu di antaranya bersifat historis. Dalam hal ini Levinson (1983:35) mengatakan bahwa "the interest developed in part as a reaction or antidote to Chomsky's treatment of language as abstract devise, or mental ability, dissociable from the users, user and function of language.." sebagaimana diketahui, Chomsky (1965: 1) mengatakan bahwa teori linguistik berkenaan terutama dengan "an ideal speaker-listener, in a completely homogeneous speech-community, who knows its language perfectly and is unaffected by such grammatically irrelevant conditions as memory limitations, distructions, shifts of attention and interest, and error in applying his knowledge of the language in actual perfomance."

Disamping itu, terdapat sejumlah motivasi yang menyebabkan berkembangnya teori pragmatik. Salah satu yang paling penting adalah kemungkinan bahwa pragmatik dapat menyebabkan penyederhanaan semantik. Harapan ini didasarkan pada kenyataan bahwa prinsipprinsip pragmatik penggunaan bahasa dapat lebih memahami makna ujaran yang tidak dapat secara tuntas dapat dipahami dari makna 
harfiahnya (semantics) saja. Faktor lain yang bersifat substansial adalah adanya kesenjangan antara teori bahasa yang berkenaan dengan pembentukan sejumlah rumus/pola tertentu untuk dapat menghasilkan kalimat-kalimat yang jumlahnya tidak terbatas, orang mungkin berkesimpulan bahwa teori tersebut dapat memberikan pencerahan tentang bagaimana berkomunikasi dengan menggunakan bahasa.

Namun, ketika Ia menemukan kenyataan bahwa makna bahasa hanya dibatasi pada aspek semantik, bukan kepuasan yang ditemuinya melainkan kekecewaan. Diakui bahwa semantik sangat penting dalam komunikasi, tetapi sumbangannya dapat dikatakan kecil dalam pemahaman makna bahasa secara umum. Akhirnya, kemunculan kajian pragmatik juga disebabkan oleh adanya kemungkinan bahwa penjelasan fungsional yang signifikan dapat diberikan kepada faktafakta linguistik. Lazimnya penjelasan-penjelasan linguistik hanya bersifat internal. Artinya, fitur-fitur linguistik dijelaskan dengan merujuk pada fitur-fitur linguistik yang lain atau pada aspek-aspek teori linguistik itu sendiri. Dalam kenyataannya, terdapat kemungkinan penjelasan lain yang datang dari luar aspek linguistik (Levinson, 1983).

\section{Antara Pragmatik dan Semantik}

Pragmatik dan semantik keduanya membicarakan makna. Perbedaan keduanya terletak pada penggunaan kata kerja to mean sebagaimana dalam pertanyaan berikut ini (Leech, 1983).

1. What does $\mathrm{X}$ mean? (Apa arti $\mathrm{X}$ ?)

2. What do you mean by $X$ ? (Apa maksudmu dengan $X$ ?)

Pada umumnya semantik menganggap makna sebagai suatu hubungan yang melibatkan dua segi (dyadic), seperti pada kalimat (1) sedangkan pragmatik menganggap makna sebagai suatu hubungan yang melibatkan tiga segi (triadic), sebagaimana tercermin pada kalimat (2) di atas. Dengan demikian, dalam pragmatik makna diberi definisi dalam kaitannya dengan penutur, sedangkan dalam semantik makna didefinisikan semata-mata sebagai ciri-ciri ungkapan dalam bahasa tertentu yang terpisah dari penuturnya (Leech, 1983). 
Pendapat lain mengatakan bahwa perbedaan antara semantik dan pragmatik terletak pada konteks. Meskipun antara pragmatik dan semantik memiliki perbedaan namun disisi lain kedua bagian linguistik ini justru memiliki hubungan yang sinergis dan saling melengkapi walaupun agak sulit untuk dibuktikan secara obyektif. Namun dalam hal ini menurut Leech (1993:8) dapat dilakukan suatu pembenaran dengan cara negatif, yaitu dengan menunjukkan kegagalan-kegagalan atau kelemahan pandangan ini. Pandangan yang lain adalah pertama, penggunaan makna seperti pada kalimat (1) dan contoh kalimat (2) di atas termasuk bidang semantik. Kedua, penggunaan makna pada contoh tersebut di atas termasuk bidang pragmatik. Lebih jelasnya ketiga pandangan tersebut di atas dapat dilihat pada bagan berikut ini:

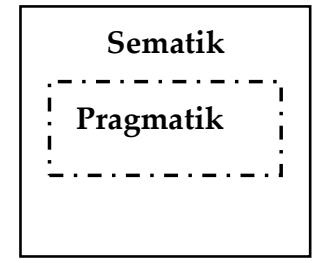

Semantisme

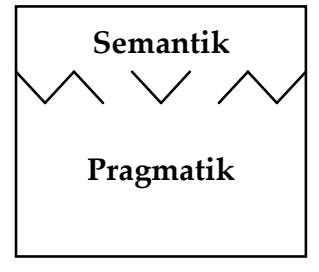

Komplementerisme

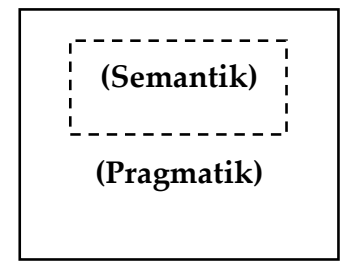

Semantisme

Berdasarkan bagan di atas, menunjukkan bahwa betapa sulitnya untuk merumuskan semantisme dan pragmatisme serta meberikan contoh-contonya. Karena itu, menurut Leech (1993:9) lebih mengacu kepada mereka yang lebih banyak memasukkan kajian makna kedalam posisi semantisme, dan pragmatisis mengacu kepada mereka yang lebih banyak memasukkan kajian makna kedalam posisi pragmatisme.

Berdasarkan hal di atas, Joko Nurkamto (2000) menyimpulkan bahwa kajian semantik cenderung mengkaji makna yang terlepas dari konteks ujaran. Sedangkan pragmatik membicarakan makna dengan mempertimbangkan konteks ujaran tersebut. Oleh karena itu, dalam memahami ujaran semisal: "Gadis itu cantik," semantik hanya 
mempertimbangkan faktor-faktor internal bahasa dalan ujaran itu, yaitu kosa kata dan hubungan antar kosa kata itu; sedangkan pragmatik mempertimbangkan siapa yang mengatakan kalimat itu, di mana, kapan, dan dalam situasi apa, di samping faktor-faktor internal bahasanya. Bagi semantik, ujaran di atas hanya berarti pemberitahuan bahwa gadis itu berwajah cantik; namun bagi kajian pragmatik ujaran di atas dapat berarti ganda, yaitu: pemberitahuan bahwa gadis itu berwajah cantik, anjuran atau keingnan bagi seorang pemuda untuk mengenali dan mendekatinya, atau yang lebih dari sekedar itu tergantung pada konteksnya.

Meskipun berbeda, dalam memahami makna suatu ujaran keduanya bekerjasama secara komplementer. Artinya, makna suatu ujaran tidak dapat hanya didekati dari salah satu satu sisi, baik semantik maupun pragmatik, melainkan harus dilihat dari keduanya. Dalam contoh di atas, misalnya, orang tidak akan dapat memahami bahwa ujaran "Gadis itu cantik" berarti anjuran atau keingnan bagi seorang pemuda untuk mengenali dan mendekatinya (Pragmatics). Apabila ia tidak memahami makna dasarnya maka hal itu masuk bidang semantik (semantics).

\section{Sumber Kajian Pragmatik}

Pragmatik sebagai ilmu bersumber pada beberapa ilmu lain yang juga mengkaji bahasa dan faktor-faktor yang berkaitan dengan penggunaan bahasa ilmu-ilmu itu ialah filsafat bahasa, sosiolinguistik antropologi, dan linguistik - terutama analisa wacana (discourse analysis)dan toeri deiksis (Nababan, 1987). Dari filsafat bahasa pragmatik mempelajari tindak tutur (speech act) dan conversational implicature. Dari sosiolinguistik, pragmatik membicarakan variasi bahasa, kemampuan komunikatif, dan fungsi bahasa. Dari antropologi pragmatik mempelajari etika berbahasa, konteks berbahasa, dan faktor non verbal. Dari linguistik dan analisa wacana dibicarakan lebih dalam pada bagian-bagian selanjutnya. 


\section{Obyek Kajian Pragmatik}

Pada uraian sebelumnya telah dikemukakan bahwa pragmatik mengacu pada kajian penggunaan bahasa yang berdasarkan pada konteks. Bidang kajian yang berkenaan dengan hal itu - yang kemudian lazim disebut bidang kajian pragmatic adalah deiksis (dexis), praanggapan (presupposition), tindak tutur (speech act), dan implikatur percakapan (conversational inplicature). Masing bidang kajian di atas dibahas secara singkat di bawah ini:

\section{Deiksis (Dexis)}

Deiksis adalah gejala semantik yang terdapat pada kata atau konstruksi yang hanya dapat ditafsirkan acuannya dengan mempertimbangkan konteks pembicaraan (Hasan Alwi, dkk., 1998). Kata saya, sini, sekarang, misalnya, tidak memiliki acuan yang tetap melainkan bervariasi tergantung pada berbagai hal. Acuan dari kata saya menjadi jelas setelah diketahui siapa yang mengucapkan kata itu. Kata sini memiliki rujukan yang nyata setelah di ketahui di mana kata itu di ucapkan. Demikian pula, kata sekarang ketika diketahui pula kapan kata itu diujarkan. Dengan demikian kata-kata di atas termasuk katakata yang deiktis. Berbeda halnya dengan kata-kata seperti meja, kursi, mobil, dan komputer. Siapapun yang mengatakan, di manapun, dan kapanpun, kata-kata tersebut memiliki acuan yang jelas dan tetap.

Bayangkan, ketika seorang mahasiswa UIN mendapati tulisan di sebuah mikrolet jurusan GL/LG, yang bertuliskan hari ini bayar, besok gratis. Demikian pula di dalam sebuah warung makan di sekitar tempat kos mahasiswa, dijumpai sticker yang bertuliskan Hari ini bayar, besok boleh ngutang. Ungkapan-ungkapan di atas memiliki arti hanya apabila diujarkan oleh sopir mikrolet di hadapan para penumpangnya atau oleh pemilik warung makan di depan para pengunjung warung makannya.

Deiksis dapat di bagi menjadi lima kategori, yaitu deiksis orang (persona), waktu (time), tempat (place), wacana (discourse), dan sosial (social) (Levinson, 1983). Deiksis orang berkenaan dengan penggunaan 
kata ganti persona, seperti saya (kata ganti persona pertama), kamu (kata ganti persona kedua). Contoh Bolehkah saya datang kerumahmu? Kata saya dan -mu dapat dipahami acuannya hanya apabila diketahui siapa yang mengucapkan kalimat itu, dan kepada siapa ujaran itu ditujukan.

Deiksis waktu berkenaan dengan penggunaan keterangan waktu, seperti kemarin, hari ini, dan besok. Contoh, Bukankah besok hari libur? Kata besok memiliki rujukan yang jelas hanya apabila diketahui kapan kalimat itu diucapkan.

Deiksis tempat berkenaan dengan penggunaan keterangan tempat, seperti di sini, di sana, dan di depan. Contoh duduklah di sini!. Kata di sini memiliki acuan yang jelas hanya apabila diketahui dimana kalimat itu diujarkan.

Deiksis wacana berkaitan dengan penggunaan ungkapan dalam suatu ujaran untuk mengacu pada bagian dari ujaran yang mengandung ungkapan itu (termasuk ungkapan itu sendiri), seperti berikut ini, pada bagian lalu, dan ini. Contoh, kata that pada kalimat that was the funniest story ever heard. Penanda wacana yang menghubungkan kalimat yang satu dengan kalimat lain. Seperti any way, by the way, dan di samping itu juga termasuk dalam deiksis wacana. Deiksis sosial berkenaan dengan aspek ujaran yang mencerrminkan realitas sosial tertentu pada saat ujaran itu dihasilkan. Penggunaan kata Bapak pada kalimat "Bapak dapat memberi kuliah hari ini?" Yang diucapkan oleh seorang mahasiswa kepada dosennya mencerminkan deiksis sosial. Dalam contoh di atas dapat diketahui tingkat sosial pembicara dan lawan bicara. Lawan bicara memiliki tingkat sosial yang lebih tinggi dari pada pembicara.

\section{Praanggapan (Presupposition)}

Praanggapan adalah apa yang digunakan penutur sebagai dasar bersama bagi para peserta percakapan (Brown dan yule, 1996); atau "What a speaker or writer assumes that the receiver of the missage alredy knows"(Richards, Platt, dan platt, 1993). Asumsi tersebut ditentukan batas-batasannya berdasarkan anggapan-anggapan pembicara 
mengenai apa yang kemungkinan akan diterima oleh lawan bicara tanpa tantangan. Sebagai ilustrasi perhatikan percakapan di bawah ini:

A: What about inviting John tonight?

B: What a good idea; then he can give Monica a lift

Praanggapan yang terdapat dalam percakapan di atas antara lain adalah (1) Bahwa A dan B kenal dengan John dan Monica, (2) bahwa John memiliki kendaraan - kemungkinan besar mobil, dan (3) bahwa Monica tidak memiliki kendaraan saat ini (Richard, Platt, dan Platt, 1993).

Dari contoh di atas dipahami bahwa apabila suatu kalimat diucapkan, selain dari makna yang dinyatakan dengan pengucapan kalimat itu, turut tersertakan pula tambahan makna, yang tidak dinyatakan dengan pengucapan kalimat itu (Bambang Kaswanti Purwo, 1990).

\section{Tindak Tutur (Speech Act)}

Tindak tutur adalah adalah suatu tuturan /ujaran yang merupakan satuan fungsional dalam komunikasi (Richard, Platt, dan Platt, 1993). Teori tindak tutur di kemukakan oleh dua orang ahli filsafat bahasa yang bernama John Austin dan John Searle pada tahun 1960-an. Menurut teori tersebut, setiap kali pembicara mengucapkan suatu kalimat, Ia sedang berupaya mengerjakan sesuatu dengan katakata (dalam kalimat) itu. Menurut istilah Austin (1965: 94), " By saying something we do something". Seorang hakim yang mengatakan "dengan ini saya menghukum kamu dengan hukuman penjara selama lima tahun" sedang melakukan tindakan menghukum terdakwa. Kata-kata yang diucapkan oleh hakim tersebut menandai dihukumnya terdakwa. Terdakwa tidak akan masuk penjara tanpa adanya kata-kata dari hakim (Clark dan Clark, 1977:26). 
Kata-kata yang diungkapkan oleh pembicara memiliki dua jenis makna sekaligus, yaitu makna proposisional atau makna lokusioner (locutionary meaning) dan makna ilokusioner (illocutionary meaning). Makna proposisional adalah makna harfiah kata-kata yang terucap itu. Untuk memahami makna ini pendengar cukup melakukan decoding terhadap kata-kata tersebut dengan bekal pengetahuan gramatikal dan kosa kata. Makna ilokusioner merupakan efek yang ditimbulkan oleh kata-kata yang diucapkan oleh pembicara kepada pendengar. Sebagai ilustrasi, dalam ungkapan "saya haus" makna proposisionalnya adalah pernyataan yang menggambarkan kondisi fisik pembicara bahwa Ia haus. Makna ilokusionernya adalah efek yang diharapkan muncul dari pernyataan tersebut terhadap pendengar. Pernyataan tersebut barangkali dimaksudkan sebagai permintaan kepada pendengar untuk menyediakan minuman bagi pembicara.

Searle (1986) dalam Joko Nurkamto (2000) membagi tindak tutur menjadi lima. Pertama adalah komisif (commisive), yaitu tindak tutur yang menyatakan bahwa pembicara akan melakukan sesuatu di masa akan datang, seperti janji atau ancaman. Contoh, Saya akan melamarmu bulan depan. Kedua, adalah deklaratif (declarative), yaitu tindak tutur yang dapat mengubah keadaan. Contoh, Dengan ini Anda saya nyatakan lulus. Kata-kata tersebut mengubah status seseorang dari keadaan belum lulus ke keadaan lulus. Ketiga, adalah direktif (directive), yaitu tindak tutur yang berfungsi meminta pendengar untuk melakukan sesuatu seperti saran, permintaan, dan perintah. Contoh, Silahkan duduk!. Keempat, adalah ekspresif (expressive), yaitu tindak tutur yang digunakan oleh pembicara untuk mengungkapkan perasaan dan sikap terhadap sesuatu. Contoh Mahasiswi itu cantik sekali. Kelima, adalah representatif (representative), yaitu tindak tutur yang menggambarkan keadaan atau kejadian, seperti laporan, tuntutan, dan pernyataan. Contoh, Ujian Akhir Semester dimulai pukul tujuh.

Dari uraian di atas tampak bahwa tindak tutur (speech act) merupakan fungsi bahasa (language function), yaitu tujuan digunakan bahasa, seperti untuk memuji, meminta maaf, memberi saran, dan mengundang. Fungsi-fungsi tersebut tidak dapat ditentukan hanya dari bentuk 
gramatikalnya, tetapi juga dari konteks digunakannya bahasa tersebut. Sebagai contoh, Kalimat deklaratif yang secara tradisional digunakan untuk membuat pernyataan (statement) dapat digunakan untuk menyatakan permintaan atau perintah (Sinclair dan Coulthard, 1975).

Oleh karena itu, dalam teori tindak tutur (speech act) dikenal istilah tindak tutur tidak langsung (indirect speech act), yaitu tindak tutur yang dikemukakan secara tidak langsung. Bandingkan kedua ujaran berikut ini, yang diucapkan seorang tamu kepada tuan rumahnya:

\section{A: Maaf lho Bu, Gelasnya bocor \\ $B$ : Bu, saya haus}

Kalimat (1) adalah contoh tindak tutur tidak langsung, dan kalimat (2) adalah kalimat contoh tindak tutur langsung. Dalam komunikasi sehari-hari, tindak tutur langsung sering dianggap lebih sopan dari pada tindak tutur langsung, terutama apabila berkaitan dengan permintaan (requests) dan penolakan (refusals).

\section{Implikatur Percakapan (Conversational Inplicature)}

Istilah implikatur dipakai oleh Grice (1975) untuk menerangkan apa yang mungkin di artikan, disarankan, atau dimaksudkan oleh penutur, yang berbeda dengan apa yang sebenarnya dikatakan oleh penutur itu (Brown dan Yule, 1996). Menurut Levinson (1983), implikatur percakapan merupakan penyimpangan dari muatan semantik suatu kalimat. Dikatakan bahwa:

"they grenerate inferences beyond the semantic content of the sentences uttered. Such inferences are, by definition, conversational implicatures, where the term implicature is intended to contrast with the term like logical implication, entaiment and logical consequences which are generally used to refer to inferences that are derived solely from logical and semantic content. For implicatures are not semantic inferences, but rather 
inferences based on both the content of what has been said and some specific assumption about the co-oprative nature of ordinary verbal interction" (103-104)

Pemahaman terhadap implikatur percakapan tidak terlepas dari asas kerja sama (co-oprative principle) yang dikemukakan oleh Grice (Brown dan Yule, 1996: 31-32). Asas umum kerja sama tersebut berbunyi:" Berikan sumbangan anda pada percakapan sebagaimana diperlukan, pada tahap terjadinya, oleh tujuan yang diterima atau arah pertukaran pembicaraan yang anda terlibat di dalamnya." Asas umum tersebut menurut Joko Nurkamto (2000) dapat direfleksikan dari beberapa maksim, yaitu: 1) Maksim Kuantitas: Berikan informasi anda seimformatif yang diperlukan (sesuai dengan percakapan sekarang. Jangan memberikan informasi yang lebih informatif dari yang diperlukan, 2) Maksim Kualitas: Jangan megatakan apa yang anda yakini tidak benar. Jangan mengatakan sesuatu apabila anda tidak memiliki bukti tentangnya, 3) Maksim Hubungan: Berbicaralah yang relevan, dan 4) Maksim Cara: Nyatakan dengan jelas. Hindarkan ungkapan yang kabur. Hindarkan kata-kata yang memiliki arti ganda. Berbicaralah dengan singkat (jangan bertele-tele). Berbicaralah dengan teratur.

Pengingkaran terhadap maksim-maksim di atas mengakibatkan lahirnya arti tambahan pada arti harfiah ujarannya. Arti tambahan itu merupakan implikatur percakapan. Perhatikan contoh perrcakapan antara A dan B berukut ini:

\section{A: I am out of petrol \\ $B$ : There is garage round the corner.}

Dari percakapan di atas tampak bahwa B melanggar maksim hubungan (berbicaralah yang relevan). Implikaturnya, yang berasala dari anggapan B menganut asas kerja sama, adalah (1) bahwa ada pompa bensin di sudut jalan; (2) bahwa pompa bensin tersebut masih 
buka dan menjual bensin; dan (3) bahwa di balik sudut jalan yang dimaksud bukanlah jarak yang jauh. Di samping itu, kita harus menafsirkan bahwa kata-kata A tidak hanya merupakan deskripsi keadaan tertentu saja, melainkan juga sebagai permintaan bantuan, misalnya.

\section{Penutup}

Sebagai kata akhir dari paparan ini, penulis menyimpulkan bahwa dalam pragmatik umum senntiasa mengupas hal-hal yang bersifat lokal dan situasional serta dapat diatur dalam sosiopragmatik (sociopragmatics) dan pragmalinguistik (pragmalinguistics), karena memang kedua bidang ini merupakan cabang dari pragmatik umum yang memiliki hubungan yang sinergi. Sosio-pragmatik memiliki kesamaan dengan istilah ketepatan isi (appropriateness in meaning), yaitu sejauh mana fungsi komunikasi tertentu, sikap dan gagasan dianggap tepat sesuai dengan situasi yang berlaku. Hal ini berhubungan erat dengan aspek sosiologi. Bahkan, dalam berkomunikasi seorang penutur dituntuk untuk menguasai kajian lintas budaya (cross culture), hal ini dilakukan dalam rangka membangun prinsip-prinsip kerjasama dan sopan santun dalam proses komunikasi, sehingga tujuan komunikasi dapat dicapai secara efektif dan menghindari kesalahfahaman anatar penutur dan lawan tutur.

\section{DAFTAR PUSTAKA}

Austin, J.L. 1965 How to do Things with Word. Oxfort: Oxford Univercity Press.

Bambang Kaswanti Purwo. 1984. Deiksis dalam Bahasa Indonesia. Jakarta: Balai Pustaka, 1990. Pragmatik dan Pengajaran Bahasa. Yogyakarta: Kanisius. 
Brown, Gillian dan Yule., George. 1996. Analisis Wacana. Jakarta: PT. Gramedia Pustaka Utama.

Canale, Michael. 1983. "From Communicative Competence to Communicative Language Pedagogy. " dalam Richard, Jack C. dan Schmidt E. (Eds). Language and Communication. London: Longman.

Chomsky, Noam. 1965. Aspects of the Theory of Sintax. Cambridge: the M.I.T. Press.

Clark, Herbert H. dan Clark Eve V. 1977. Psychology of Language. New York: Hartcourt Brace Javanivich, Inc.

Hasan Alwi dkk. 1998. Tata Bahasa Baku Bahasa Indonesia. Jakarta: Balai Pustaka.

James, Carl. 1980. Contrastive Analysis. London: Longman.

Joko Nurkamto. 2000. Makalah, Pragmatik. PPS UNS Surakarta.

Leech, Geoffrey. 1997. Prinsip-Prinsip Pragmatik. (Terj. Dr. M.D.D. Oka). Jakarta :UI Press.

Levinson, Stephent C. 1983. Pragmatics. Cambridge: Cambridge Univercity Press.

Nababan, P.W.J. 1987. Ilmu Pragmatik: Teori dan Penerapannya. Jakarta: Depdikbud.

Richard, Jack C,; Platt, John; dan Platt, Heidi. 1993. Longman Dictionary of Language Teaching and Applied Linguistics. England: Longman.

Searle, John R. 1986. Expression and Meaning: Studies in the Theory of Speech Acts. Cambridge: Cambridge Univercity Press.

Sinclair, J. Mch. dan Choulthards, R.M. 1984. Toward an Analysis of Discourse: The English Used by Teachers and Pupils. London: Oxford Univercity Press.

Thomas, Jenny. 1983." Cross Cultural Failure." Applied Linguistics, 91112.

Van Ek, JA. dan Trim, J. L. M.1991. Threshold 1990. Cambridge: Cambridge Univercity Press. 
